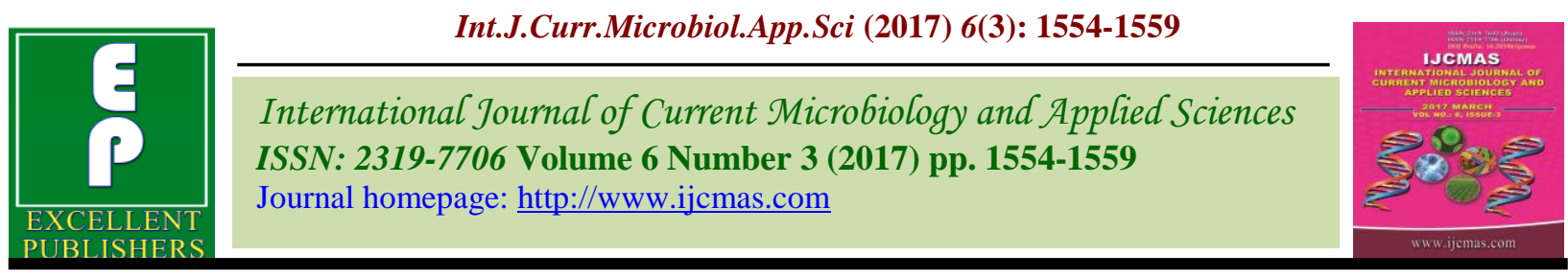

Original Research Article https://doi.org/10.20546/ijcmas.2017.603.178

\title{
Evaluation of Pumpkin (Cucurbita moschata L.) Genotypes for Earliness, Yield and Quality
}

\author{
N.A. Tamilselvi ${ }^{1}$ * and P. Jansirani ${ }^{2}$ \\ ${ }^{1}$ Department of Vegetable Crops, Horticulture College and Research Institute, \\ Tamil Nadu Agricultural University, Coimbatore, India \\ ${ }^{2}$ Department of Spices and Plantation Crops, Horticulture College and Research \\ Institute, Periyakulam, India \\ *Corresponding author
}

\begin{tabular}{|c|c|}
\hline & A B S T R A C T \\
\hline & \multirow{7}{*}{$\begin{array}{l}\text { In the recent time, pumpkin has got industrial importance with the development of pulp } \\
\text { powder as a nutraceutical supplement to Vitamin A requirement. Pumpkin is cheaper } \\
\text { source of Vitamin A when compared to carrot which necessitates specific climatic } \\
\text { requirement for its production and high productivity per unit area. An experiment was } \\
\text { conducted at the Department of Vegetable Crops, Horticulture College and Research } \\
\text { Institute, Tamil Nadu Agricultural University, Coimbatore to find out suitable pumpkin } \\
\text { genotype for earliness, high yield and quality. About } 15 \text { pumpkin genotypes collected from } \\
\text { various places were evaluated for different quantitative characters viz., vine length, days to } \\
\text { first female flower appearance, node number for first female flower appearance, sex ratio, } \\
\text { days to first harvest, fruit number per vine, fruit weight (kg), flesh thickness }(\mathrm{cm}) \text { and fruit } \\
\text { yield per vine (kg/vine) and quality parameters viz., total carbohydrate content and total } \\
\text { carotenoid content. Analysis of variance revealed that mean sum of squares due to } \\
\text { genotypes was highly significant for all characters. The result revealed that among the } 15 \\
\text { genotypes Vadhalagundu local, Kasi Harit and Arka Suryamukhi, CO } 12 \text { excelled for } \\
\text { earliness, fruit yield and quality parameters }\end{array}$} \\
\hline & \\
\hline Pumpkin, & \\
\hline & \\
\hline Article Info & \\
\hline $\begin{array}{l}\text { Accepted: } \\
\text { 22 February } 2017 \\
\text { Available Online: } \\
10 \text { March } 2017\end{array}$ & \\
\hline & \\
\hline
\end{tabular}

\section{Introduction}

Cucurbitaceae is one of the largest families in vegetable kingdom consisting of largest number of edible species. There are 27 species under the genus Cucurbita, five of which are in cultivation. These are Cucurbita moschata, Cucurbita maxima, Cucurbita ficifolia, Cucurbita pepo and Cucurbita mixta. Cucurbita moschata is commonly known as pumpkin and widely cultivated species of Cucurbita and the fruit is valued for its long storage capacity and high nutritious value (Jahan et al., 2012). This species is cross compatible with $C$. maxima, $C$. pepo and $C$. mixta (Tindall, 1987). Pumpkin fruits are extensively used as vegetables both in immature and mature stage and the matured fruits can be stored for 2-4 months (Yawalkar, 1991). The yellow and orange fleshed fruits are very rich in carotene $(3,332 \mathrm{IU})$, which is precursor of Vitamin-A with fair quantities of vitamins $B$ and $C$. It may contribute to improve the nutritional status of the people, particularly the vulnerable groups with respect to vitamin A requirement (Satkar et 
al., 2013). In India, pumpkin is cultivated over an area of 5400 ha, with a total production of 1197 MT and the productivity is about 22.2 MT/ha (Anon., 2015-16). The pumpkin produced in India is mainly used for domestic consumption as fresh vegetable. The mature fruits, apart from the main use as vegetables, are also utilized as industrial raw material for carotene production (Vucetic et al., 1989). Pumpkin, as pulp powder is exported in a limited volume. A vast scope exists for increasing the production and export of pumpkin to enhance foreign exchange.

In pumpkin the major problem in consumer preference is large sized fruits $(4-5 \mathrm{~kg})$ which is not much preferred by a small family of three to four members. Further, with increased number of nuclear families of recent scenario in India, people prefer to buy only small to medium sized whole fruits of pumpkin instead of cut pieces. Further, the small fruits can be easily packed and transported without any damage. Hence, development of pumpkin varieties and hybrids with small to medium sized fruits (2-3 $\mathrm{kg}$ ) is essential. Several attempts were made both by public and private sectors to develop high yielding varieties and hybrids. However, development of high yielding varieties and hybrids coupled with medium sized fruits having high beta carotene content is very meager. Pumpkin has received little attention in crop improvement, as compared to other Cucurbitaceous vegetables. Since ancient times, a wide number of germplasms are available, conscious evaluation and exploitation of germplasm has not been attended until recently. This is very helpful for a plant breeder in developing a commercial variety with market preference by determining the component characters on which selection can be exercised based on the improvement in yield and quality. Preliminary identification of early maturing genotypes can be done based on characters like days to opening of female flowers, node number to first female flowering and days to fruit picking. Collection and evaluation of germplasm is a pre-requisite in any improvement programme to select high yielding genotypes with desirable attributes viz., earliness, high yield and quality. Therefore, a trial for characterization and evaluation of presently available pumpkin germplasm is carried out in order to identify the potential cultivar for earliness, high yielder of small to medium fruits along with improved quality parameters.

\section{Materials and Methods}

The investigation was carried out at the Department of Vegetable Crops, Horticulture College and Research Institute, Tamil Nadu Agricultural University with 15 genotypes viz., 'Pusa Vishwas', 'Punjab Samrat', 'Narendra Abhushan', 'Narendra Uphar', 'Ambili', 'Virudhachalam Local', 'Chakor', 'Ashoka Farm Aids', 'Vadhalagundu Local', 'Karamadai Local', 'Karwar Local', and 'Kasi Harit', 'Arka Suryamukhi' (Cucurbita maxima L), 'Avinashi Local' and ' $\mathrm{CO} 2$ ' collected from diverse sources. These plants are raised in randomized block design (RBD) with three replications and each replication consists of seven plants following a spacing of $2.5 \times 2.5 \mathrm{~m}^{2}$. Recommended package of practices of Tamil Nadu Agricultural University was followed to grow a successful crop of pumpkin (Anon, 1985). Observations viz., vine length, days to first female flower appearance, node number for first female flower appearance, sex ratio, days to first harvest, fruit number per vine, fruit weight $(\mathrm{kg})$, flesh thickness $(\mathrm{cm})$ and fruit yield per vine $(\mathrm{kg} / \mathrm{vine})$ on five plants of each genotypes in each replication and means of these observations were subjected to statistical analysis. The quality parameters viz., total carbohydrate content $(\mathrm{g} / 100 \mathrm{~g})$ and 
total carotenoid content $(\mathrm{mg} / 100 \mathrm{~g})$ were estimated on five fruits of each genotype per replication at harvestable maturity as per the procedure given by Hedge and Hofreiter (1962) and Roy (1973) respectively. Statistical analysis of data was carried out to estimate per se values as per the method suggested by Panse and Sukhatme (1978).

\section{Results and Discussion}

The mean values of different earliness, yield and quality parameters with respect to pumpkin genotypes are presented in table 1 . Vine length is an important parameter to get high fruit yield. Among the 15 pumpkin genotypes, the longest vine length was recorded by Ashoka Farm Aids (7.66 m) which recorded fruit yield of $9.50 \mathrm{~kg}$ per vine which was next best to the highest yield of $11.11 \mathrm{~kg}$ per vine as recorded by the genotype Ambili (5.83 m). Uma Maheshwari and Hari Babu (2005) obtained similar trend of results in pumpkin who reported the line CM-12 recorded the highest mean value for vine length among the pumpkin genotype. Earliness in cucurbits is measured as the days taken for first female flower appearance and node number for first female flower appearance which considered as desirable traits in any crop improvement programme. In the present study, minimum number of days and lesser node number for first female flower appearance was observed in the genotype Arka Suryamukhi (42.37 days and 14.50) followed by Kasi Harit (44.75 days and 16.50) which could be adjudged as the best parents for development of pumpkin hybrids with earliness. Similar results were also obtained by Suganthi (2008) in bottle gourd and Shivanand Hegde (2009) in ridge gourd.

Estimation of sex ratio is highly essential trait in crops like cucurbits. It indicates the ability of the crop to set fruits. Evaluation of parents with mean performance revealed that the genotype Kasi Harit (14.82) followed by Vadhalagundu local (17.36) were preferred as they would serve as good donors for developing hybrids with desirable sex ratio. Dey et al. (2007) reported the similar result of narrow sex ratio in bitter gourd. Observation on days to first harvest is yet another indicator of the earliness in any crop especially vegetables hybrids which could fetch premium price and catch the early market. The genotypes Narendra Uphar (101.50 days) followed by Kasi Harit (107.37 days) and Arka Suryamukhi (108.37 days) recorded the lowest favorable per se values for days to first harvest. Early reports by Shivanand Hegde (2009) in ridge gourd also provided evidence that the ridge gourd line Arka Sumeet had the lowest per se value for days to first harvest which recorded high fruit yield.

Number of fruits produced by any kind of vegetable is a direct indicator of high yield. Higher the fruit number more will be the yield. In this study, the genotype CO 2 (4.75) followed by Ashoka Farm Aids (4.25) and Vadhalagundu local (4.00) recorded the high mean values for fruit number per vine. Similar findings were reported by Suganthi (2008) and Shivanand Hegde (2009) in bottle gourd and ridge gourd respectively. Among the 15 genotypes, the highest mean value for fruit weight was recorded by the genotype Virudhachalam local $(6.84 \mathrm{~kg})$ followed by CO $2(3.35 \mathrm{~kg})$.

Though the fruit number per vine is an important trait, in recent days, preference is highest to small or medium sized fruits. In the present study the genotypes Vadhalagundu local $(2.39 \mathrm{~kg})$ and Kasi Harit $(2.35 \mathrm{~kg})$ registered comparatively lesser fruit weight in favorable direction. Earlier results recorded by Shivanand Hegde (2009) in ridge gourd also confirmed the relationship with less fruit weight and high yield favourably. 
Table.1 Analysis of variance for earliness, yield and quality components of pumpkin genotypes

\begin{tabular}{|c|c|c|c|c|c|c|c|c|c|c|c|c|}
\hline \multirow[b]{2}{*}{ Source } & \multirow[b]{2}{*}{ df } & \multicolumn{11}{|c|}{ Mean sum of squares } \\
\hline & & $\begin{array}{l}\text { Vine } \\
\text { length }\end{array}$ & $\begin{array}{l}\text { Days to } \\
\text { first female } \\
\text { flower } \\
\text { appearance }\end{array}$ & $\begin{array}{l}\text { Node no. for } \\
\text { first female } \\
\text { flower } \\
\text { appearene }\end{array}$ & $\begin{array}{r}\text { Sex } \\
\text { ratio }\end{array}$ & $\begin{array}{l}\text { Days to } \\
\text { first } \\
\text { harvest }\end{array}$ & $\begin{array}{l}\text { Fruit } \\
\text { number } \\
\text { per vine }\end{array}$ & $\begin{array}{l}\text { Fruit } \\
\text { weight }\end{array}$ & $\begin{array}{l}\text { Flesh } \\
\text { thickness }\end{array}$ & $\begin{array}{c}\text { Total } \\
\text { carbohydr } \\
\text { ate } \\
\text { content }\end{array}$ & $\begin{array}{c}\text { Total } \\
\text { carotenoid } \\
\text { content }\end{array}$ & $\begin{array}{l}\text { Fruit } \\
\text { yield } \\
\text { per } \\
\text { vine }\end{array}$ \\
\hline Replication & 2 & 0.02 & 2.20 & $2.91 *$ & $1.14 * *$ & 0.88 & 0.006 & $0.16 * *$ & $0.19 *$ & 0.0003 & 0.02 & 0.08 \\
\hline Genotypes & 50 & $3.92 * *$ & $30.28 * *$ & $19.95 * *$ & $25.79 * *$ & $339.63 * *$ & $3.41 * *$ & $1.92 * *$ & $0.47 * *$ & 0.99 & 1.62 & $17.36 * *$ \\
\hline Error & 50 & 0.01 & 0.79 & 0.58 & 0.48 & 6.22 & 0.14 & 0.02 & 0.06 & 0.001 & 0.004 & 0.04 \\
\hline
\end{tabular}

Table.2 Per se performance of pumpkin genotypes for earliness, yield and quality components

\begin{tabular}{|c|c|c|c|c|c|c|c|c|c|c|c|}
\hline Parents & $\begin{array}{l}\text { Vine } \\
\text { length } \\
\text { (m) }\end{array}$ & $\begin{array}{l}\text { Days to first } \\
\text { female } \\
\text { flower } \\
\text { appearance }\end{array}$ & $\begin{array}{l}\text { Node } \\
\text { number to } \\
\text { first female } \\
\text { flower } \\
\text { appearance }\end{array}$ & Sex ratio & $\begin{array}{l}\text { Days to } \\
\text { first } \\
\text { harvest }\end{array}$ & $\begin{array}{l}\text { Fruit } \\
\text { number } \\
\text { per vine }\end{array}$ & $\begin{array}{l}\text { Fruit } \\
\text { weight } \\
\text { (kg) }\end{array}$ & $\begin{array}{l}\text { Flesh } \\
\text { thickness } \\
(\mathrm{cm})\end{array}$ & $\begin{array}{l}\text { Total } \\
\text { carbohydrate } \\
\text { content } \\
(\mathrm{g} / 100 \mathrm{~g})\end{array}$ & $\begin{array}{l}\text { Total } \\
\text { carotenoid } \\
\text { content } \\
(\mathbf{m g} \text { per } \\
\mathbf{1 0 0} \text { g) }\end{array}$ & $\begin{array}{l}\text { Fruit } \\
\text { yield per } \\
\text { vine } \\
(\mathrm{kg})\end{array}$ \\
\hline Pusa Vishwas & 4.52 & 53.62 & 19.12 & 18.33 & 125.70 & 1.62 & 5.28 & 3.07 & 0.77 & 0.56 & 5.82 \\
\hline Punjab Samrat & 4.70 & 51.00 & 23.62 & 18.65 & 126.50 & 3.87 & 3.89 & 2.77 & 1.70 & 0.96 & 7.98 \\
\hline Narendra Abhushan & 5.78 & 49.12 & 22.87 & 27.07 & 106.75 & 2.37 & 4.22 & 3.56 & 1.84 & 0.75 & 9.47 \\
\hline Narendra Uphar & 4.72 & 50.37 & 24.62 & 19.68 & 101.50 & 4.12 & 3.35 & 2.32 & 1.78 & 0.54 & 7.92 \\
\hline Ambili & 5.83 & 50.87 & 25.62 & 24.37 & 128.50 & 2.87 & 5.08 & 2.80 & 0.73 & 0.33 & 11.11 \\
\hline Virudhachalam local & 6.60 & 63.12 & 26.62 & 27.98 & 143.75 & 1.12 & 6.84 & 3.27 & 1.99 & 1.015 & 7.54 \\
\hline Chakor & 5.17 & 52.87 & 24.87 & 19.33 & 146.75 & 3.12 & 2.83 & 3.28 & 1.14 & 0.75 & 8.40 \\
\hline Ashoka Farm Aids & 7.66 & 54.12 & 26.25 & 19.70 & 148.37 & 4.25 & 3.62 & 2.83 & 1.73 & 0.67 & 9.50 \\
\hline Vadhalagundu local & 4.06 & 48.12 & 25.87 & 17.36 & 108.75 & 4.00 & 1.95 & 3.07 & 2.77 & 2.25 & 10.11 \\
\hline Karamadai local & 4.40 & 49.50 & 17.62 & 18.21 & 128.50 & 3.37 & 2.39 & 2.36 & 1.93 & 1.065 & 8.47 \\
\hline Karwar local & 7.55 & 48.87 & 25.12 & 19.81 & 113.50 & 1.75 & 4.34 & 2.72 & 1.30 & 0.96 & 6.70 \\
\hline Kasi Harit & 5.76 & 44.75 & 16.50 & 14.88 & 107.37 & 3.75 & 2.35 & 3.48 & 2.34 & 2.045 & 8.23 \\
\hline Arka Suryamukhi & 2.71 & 42.37 & 14.50 & 19.44 & 108.37 & 1.62 & 1.93 & 1.87 & 1.05 & 0.99 & 3.61 \\
\hline Avinashi local & 5.62 & 52.12 & 16.87 & 23.64 & 146.12 & 3.25 & 3.01 & 3.02 & 2.95 & 3.00 & 7.80 \\
\hline $\mathrm{CO} 2$ & 4.73 & 44.62 & 21.12 & 18.96 & 125.62 & 4.75 & 3.35 & 3.12 & 2.31 & 1.97 & 8.56 \\
\hline SEd & 0.11 & 0.88 & 0.75 & 0.68 & 2.47 & 0.38 & 0.16 & 0.24 & 0.04 & 0.06 & 0.21 \\
\hline CD $(5 \%)$ & 0.22 & 1.78 & 1.52 & 1.38 & 4.96 & 0.76 & 0.33 & 0.49 & 0.08 & 0.13 & 0.42 \\
\hline
\end{tabular}


In recent days, pumpkin fruit flesh powder is a valued industrial product as nutrient supplement. Fruit flesh thickness is a desirable quality trait in pumpkin. Among the fifteen pumpkin genotypes, Kasi Harit (3.48 $\mathrm{cm})$ and $\mathrm{CO} 2$ (3.12) recorded the highest per se value for fruit flesh thickness. Similar finding were made by Devi et al. (1989) and Srinivasan (2003) in pumpkin genotypes CM23 and CM67 respectively (Table 2).

Selection of parents with the highest fruit yield is the primary objective in any crop improvement programme. In the present study, the genotype Ambili recorded the highest mean value of fruit yield $(11.11 \mathrm{~kg}$ per vine) followed by Vadhalagundu local (10.11 $\mathrm{kg}$ per vine) and Ashoka Farm Aids (9.50 kg per vine) recorded higher values of fruit yield per vine. These genotypes could be adjudged as the ideal donor for yield as it proved its potential to serve as the best parents for earliness and fruit number per vine.

Like ash gourd, pumpkin fruits are also utilized for preparing special kind of sweets. Estimation of total carbohydrates content among fifteen pumpkin genotypes showed that Vadhalagundu local $(2.77 \mathrm{~g}$ per $100 \mathrm{~g})$ recorded the highest per se value for total carbohydrates content, followed by Avinashi local (2.95 g per $100 \mathrm{~g})$. Hence these genotypes can be utilized to develop hybrids with more total carbohydrates content. These results were supported by the findings of Shivanand Hegde (2009) in ridge gourd line IC413577 and the tester IC 362481. Total carotenoids content in pumpkin is nutritionally important parameter. Next to carrot, pumpkin is the cheapest source of carotene. Extraction of pumpkin flesh powder as source of carotene can be exploited very well on industrial level as nutraceuticals. Among the fifteen pumpkin genotypes, Avinashi local $(3.00 \mathrm{mg}$ per $100 \mathrm{~g}$ ) recorded highest per se value for total carotenoids content followed by Vadhalagundu local (2.25 mg per $100 \mathrm{~g}$ ). These parents can be involved further to develop hybrids with high carotene content. Similar findings were made by Nisha (1999) in pumpkin parental lines $\mathrm{P}_{3}$ (CM31) and $\mathrm{P}_{5}(\mathrm{CO} 2)$.

In conclusion selection of parents with the highest fruit yield is the primary objective in any crop improvement programme. Based on the present study, among the fifteen pumpkin genotypes, the genotype Ambili recorded the highest mean value of fruit yield $(11.11 \mathrm{~kg}$ per vine) followed by $\mathrm{CO} 2$ (8.56 kg per vine). Further the accessions Vadhalagundu local (10.11 kg per vine) and Ashoka Farm Aids (9.50 kg per vine) also recorded higher values of fruit yield per vine. Further these lines viz., Ashoka Farm Aids, Vadhalagundu local and $\mathrm{CO} 2$ could be adjudged as the ideal donor for yield as it proved its potential to serve as the best parents for earliness and fruit number per vine also. This study clearly indicated that favourable varieties could be developed with earliness, more number of fruits per vine, more flesh thickness coupled with high carotene content in pumpkin fruits suitable for neutraceticals industry.

\section{References}

Anon., 1985. Crop production manual. Tamil Nadu Agric. Univ., Coimbatore.

Anon.,2015-16. www.indiastat.com/table/ agriculture/2/pumpkinsitaphalkaddu/9 62223/962485/data

Devi, S.D., R. Balakrishnan, D. Paulas, R. Subbiah and S.Natarajan, 1989.Evaluation studies in pumpkin. South Indian Hort., 37(5): 274-276.

Dey, S. S., T. K. Behra, A. D. Munshi and P.S. Sirohi, 2007. Studies on genetic divergence in bitter gourd (Momordica charantia L.). Indian J. Hort., 64 (1): 5357

Hedge, J.E. and B.T. Hofreiter, 1962. 
Carbohydrates, p. 17-22. In: R.L. Whistler and J.N. BeMiller (eds.). Methods in carbohydrate chemistry. Vol. 17. Academic Press, New York.

Jahan, T.A., A.K.M.A.Islam, M.G. Rasul, M.A.K. Mian and M.M. Haque, 2012. Heterosis Of Qualitative And Quantitative Characters In Sweet Gourd (Cucurbita moschata Duch.ex Poir), African J. Food, Agr. Nutr. Dev., 12(3): 6186-6199.

Nisha, S. K. 1999. Genetic studies in pumpkin (Cucurbita moschata Duch. ex. Poir.) through diallel analysis. M.Sc. (Hort.) Thesis, Tamil Nadu Agric. Univ., Coimbatore.

Panse, V. G. and P. V. Sukhatme, 1978. Statistical methods for Agricultural Workers. I.C.A.R., New Delhi.

Roy, S.K, 1973. A simple and rapid method of estimation of total carotenoid pigment in mango. J. Food Sci. Technol., 10(1): 45.

Satkar, K. P., A. A. Kulthe and P. R. Chalke, 2013. Preparation of bitter gourd ready-to-serve beverage and effect of storage temperature on its keeping quality. The Bioscan. 8(1): 115-117.

Shivanand Hegde. 2009. Studies on heterosis in ridge gourd. M.Sc. Thesis. Tamil Nadu Agric. Univ., Coimbatore.

Srinivasan. M. 2003. Studies on genetic parameters and characterization in pumpkin (Cucurbita moschata Duch ex. Poir). M.Sc. Thesis. Tamil Nadu Agric.Univ., Coimbatore.

Suganthi, M. 2008. Line x tester analysis in bottle gourd (Lagenaria siceraria $\mathrm{M}$.) M.Sc. Thesis. Tamil Nadu Agric.Univ., Coimbatore.

Uma Maheshwari and K. HariBabu, 2005. Combining ability for yield and its components in F3 generation of pumpkin (Cucurbita moschata Duch. ex Poir.). Madras Agric.J., 92 (4-6): 288-292.

Vucetic, J., M. Cirovic and V. Matic, 1989. Chemical composition, nutritive value and healing properties of the pumpkin (Cucurbita maxima Duch.). Hrana-IIshrana, 30: 159-161.

Yawalkar KS Vegetable crop in India. AgriHorticultural Publishing House, Nagpur, 1991: 182-186.

\section{How to cite this article:}

Tamilselvi, N.A. and Jansirani, P. 2017. Evaluation of Pumpkin (Cucurbita moschata L.) Genotypes for Earliness, Yield and Quality. Int.J.Curr.Microbiol.App.Sci. 6(3): 1554-1559. doi: https://doi.org/10.20546/ijcmas.2017.603.178 